\title{
TRADICIJSKI I SUVREMENI LOV
}

Marijeta RAJKOVIĆ

Filozofski fakultet Sveučilišta u Zagrebu

Odsjek za etnologiju i kulturnu antropologiju

Ivana Lučića 3, 10000 Zagreb

\section{UVOD}

U tradicijskome gospodarstvu Krivoga Puta lov na divlje životinje imao je značajnu ulogu. Životinje su najvećim dijelom lovljene bez vatrenoga oružja, budući da su ga tek rijetki pojedinci posjedovali. Kao razlog kazivači navode to što je područje Mrzloga Dola nakon Drugoga svjetskog rata tretirano kao mjesto koje se izravno povezivalo s ustaškim pokretom, ${ }^{1}$ pa nitko nije smio imati vatreno oružje: Bože sačuvaj, tu je bila velika strogoća. Jako teško se nabavljalo oružje. ${ }^{2} \mathrm{No}$, kroz razgovore s kazivačima saznaje se da su pojedinci ipak ilegalno posjedovali oružje, odnosno pušku čekičaru, za koju se upotrebljavao crni barut i koja je jako dimila. Osim nje koristili su i puške sačmarice na bezdimni barut. Unatoč tome, tradicijski lov na divlje životinje podrazumijevao je uglavnom lov bez vatrenoga oružja, a njegovo korišstenje bilo je dopuna za ubijanje vuka i opasnijih velikih životinja.

Ovaj rad kronološki pokriva razdoblje 20. stoljeća i u njemu je osim tradicijskoga lova dan kratak prikaz lova unutar Lovačkoga društva. Naime, pojedini Krivopućani, ponajviše oni koji danas stanuju u Senju, članovi su Lovačkoga društva Jarebica. Lovačko društvo 'Jarebica'- Senj osnovano je 15. travnja 1930. godine. (Jurčenko et al. 2005:17) Od istog autora saznajemo da je prije službenog osnivanja Lovačkog društva 'Jarebica' u Senju bilo lovaca učlanjenih u Savez lovačkih društava za Hrvatsku i Slavoniju u Zagrebu (...) poslije Drugog svjetskog rata Jarebica (...) nastavlja djelovati kao Kotarsko lovačko drustvo sa sekcijama u Krivom Putu, Sv. Jurju i Jablancu. (Ibid. 17-18) Stoga su i pojedini Krivopućani bili članovi Lovačkoga društva. (sl. 1, 1a)

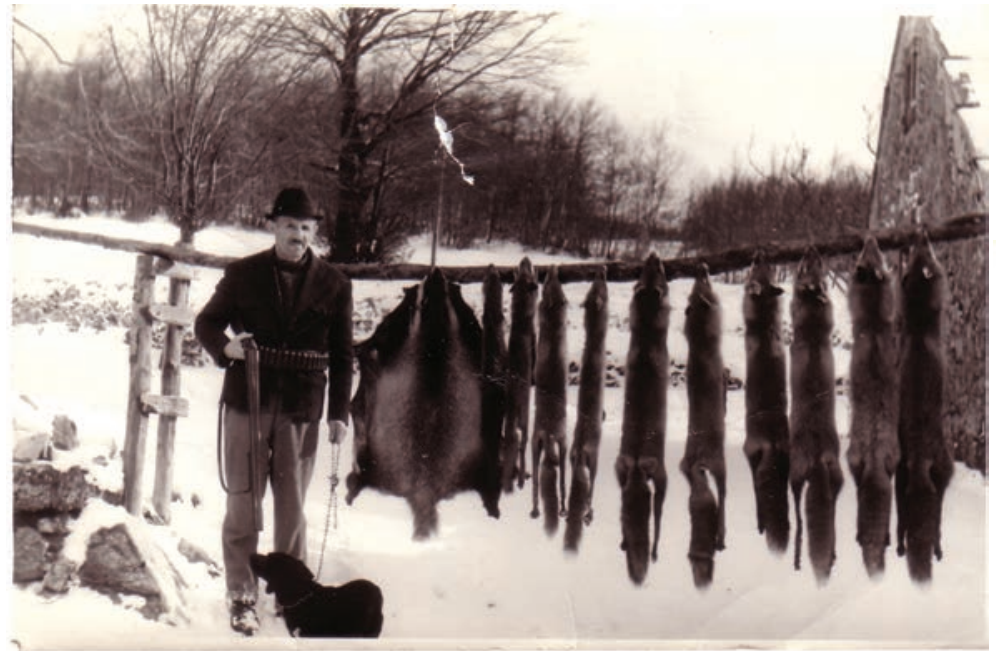

Slika 1: Kože izu ulova od lovne sezone 1969. godine i lovac Petar Tomljanović Pešo, Krivi Put; snimatelj nepoznat.

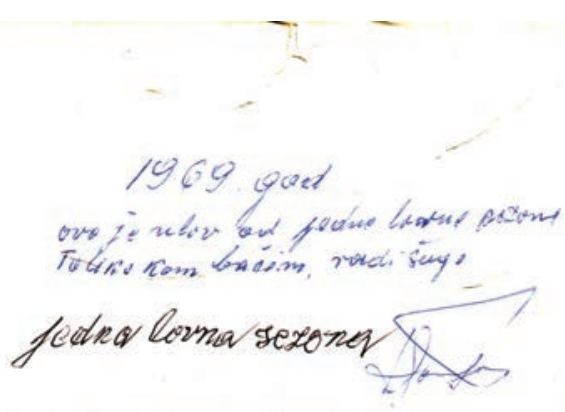

Slika 1a: Poledina fotografije.

1 Na području Mrzloga Dola nalazi se zaselak Pavelići u kojem su živjeli preci Ante Pavelića prije nego su odselili u Bradinu u Hercegovini. Ante Pavelić bio je ustaški poglavnik u Nezavisnoj Državi Hrvatskoj.

2 Mladen Šojat Bilin, Senj; isto su potvrdili: Milan Tomljanović Perǐ̌a, Alan; Ivan Krmpotić Bokula, Veljun; Luka Krmpotić Brnde, Veljun; Mile Špalj Kebin, Krivi Put; Milan Pavelić Sikirica, Mrzli Dol; Milan Pavelić Vranić, Mrzli Dol; Josip Prpić Jurina, Mrzli Dol; Marko Prpić Rus, Mrzli Dol; Milan Šojat Colaš, Francikovac; Milan Tomljanović Kanada, Podbilo. 


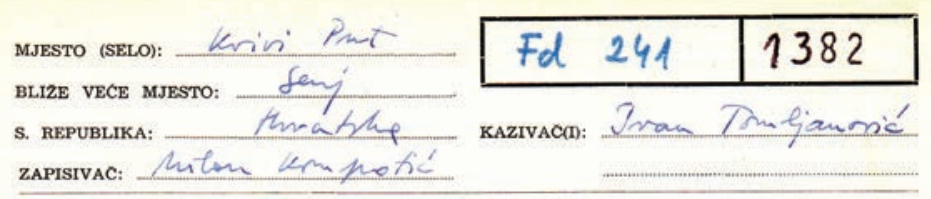

29. LOV (BEZ VATRENOG ORUZJA)

1. Koji se načini lova upotrebljavaju: prišuljavanje (prikradanje ili?), gonjenje (hajka iil?), zasjeda (čeka, pusija ili?)?

2. Goni il se divljač (koja?) samo pješke (po snijegu ili?) illi i na konjima? Upotreblja-
vaju i se pri tom psi (kakvi?) ill ptice (sokol, jastreb, reljo ili?)?

3. Vabe II se neke životinje i ptice (koje?), kako i cime?

4. Maskira li se lovac cime (granjem, vodenim biljem, bijelim pokrivalom po snijegu ili? kod prikradanja ill zasjede?

5. Upotrebljava Ii se vatra za gonjenje zvjeradi (koje?) ill dim za izgonjenje iz duplja

$$
\text { NEMA! }
$$

$58\}$

6. Sto se upotrebljava kao oružje (osim vatrenoga) i za koje žlvotinje ill ptice: kamenje, štapovi (palice), kijače (i za bacanje?), grana (za patke), nož, sjekira, metaljka (strela) za bacanje strijela, pracḱca, bodva (za kune)
jili?

7. Koje se životinje love u jame? Ima il u tim jamama zašiljen kq!a:? Postavljaju if so takovi zaşiljeni kolci ill željezni siljel n putu kojim životinje (koje?) prołaze, da bi se nabole? 8. Koje se vrste stupica III zamki upotreblja-
vaju (navesti uvijek za koje ptice, veće ili manje životinje ill kućne štetočine ševe, parcove) i kako se zovu, i to naročito: a) petlje od konjske strune, żice i sl. (ošca, [o]silo, pleniea, primki ili?; v. sl. 1, 2,3 ) - - - b) takve petije koje se zatež́ $s$ pomoću gipkoga savinutoga pruta ili mladoga drveta (sl. 4, 5; pruglo, dvigalioa, ključ ili?) - - - c) stupice koje svojom teřbnom pritisnu žlivotinju (pticu) ill je uhvate npr. kamena ploca (sl. 6; žkrij ili?), cigl klada; košara (sL. 7), koß, reseto, korito, kavez, lonac (s polovinom oraha za miseve?) tikva, škatulja (sl. 8, klonja ili?); jače klade ili brvna (sl. 9, kistine, kladice ili?) - - - d) šplje stupice koje se postavljaju pred duplje I ubijaju żivotinju težinom

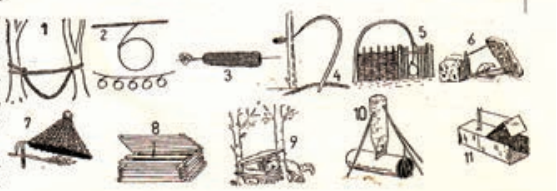

110

zaoštrenog komada drveta (sL. 10, tulae ili?) je uhvate spustanjem vratiju (sl. 11, tvorCenka za tvorove ili?) ---- e) pletene stupice za vukove ill lisice (sl. 12, 13; kotar, grư̌a ili?) ---- f) stupice koje si sklapaju snagom zapetog užeta ill tetive (sl.

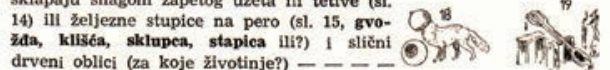
g) stupice koje se odapinju snagom zapetog luka (sl. 16; samostrel, samojster, samojstra, polhovna za puhove flit?; love 11 se puhovi i samo rukom za zimskoga sna?) $----h)$ druge vrste stupica, npr. rasječena daska $z u$ vukove (sl. 17), tikva $z a$ lisice (sl. 18) ili?

9. Da li se ptice $\mathrm{i}$ żivotinje (koje?) love razapetim mrežama (kakvim?), vř̌ama (jež, jazavae ill?) I udicama?

10. Prave li se posebni plotovi koji vode do stupica ill zamki (kakvih?)?

11. Love If se ptice na lepak (visak, bisak ili?) od čega se taj pravi?

12. Koje se sprave upotrebljavaju za plašenje divljih žlvotinja i ptica? Ima li takvih prava zovu?

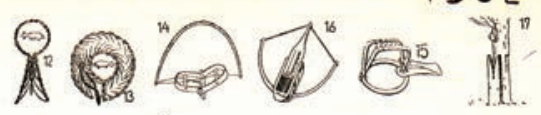


Unatoč postojanju Lovačkoga društva, iz razgovora s kazivačima može se zaključiti kako se do sedamdesetih, a često i do devedesetih godina 20. stoljeća, lovilo na zamke i stupice, dakle krivolovom. Stoga je rad podijeljen na tradicijski lov, kakav su prakticirali stanovnici ovih područja koji nisu bili lovci, te na lov u okviru Lovačkoga društva odnosno na današnje članove Lovačkoga društva. Ova se dva načina lova uvelike razlikuju, što će se vidjeti iz daljnjeg teksta. Kako je spomenuto, tradicijski i suvremeni lov možemo promatrati kroz prizmu dopune gospodarstvu. Divlje su životinje Krivopućani lovili zbog prehrane (meso), stjecanja izvora prihoda (prodaja kože i krzna), a dio suvremenoga lova, lovni turizam (od 1994. godine), možemo promatrati kao dio turističke ponude senjskoga zaleđa, a time i grada Senja što utječe na dopunu ili jedan segment dopune proračuna pojedinaca, ali i lokalne zajednice.

Kao i za ostale priloge o tradicijskom gospodarstvu i za ovaj sam prilog o lovu kao polazište koristila Upitnicu Etnološkog atlasa (UEA), tema broj 29. Lov (bez vatrenog oružja), koju sam prilikom boravka na terenu proširila i prilagodila području istraživanja te pojedinim kazivačima. Nastojala sam saznati kako se i zašto lovila pojedina životinja te gdje su nabavljali zamke. Opisan je također ophod s ubijenim vukom. Pitanja za suvremeni lov u okviru Lovačkoga društva Senj prilagodila sam pojedinom kazivaču, primjerice tajniku Lovačkoga društva Jarebica, lovočuvaru, lovcima te promatračima, odnosno Krivopućanima. Kako za tradicijski tako su i za suvremeni lov moji sugovornici (kazivači) bili muškarci. Žene su ponekad prisustvovale razgovorima, no na moja su pitanja uglavnom kazivale da ih to nikad nije zanimalo. O tradicijskom lovu na ovom području nisam pronašla podataka u literaturi, a i u Upitnici Etnološkog atlasa, koja je ispunjavana 60-ih godina 20. stoljeća, piše Nema. (sl. 2, 2a, 2b). Podatke o suvremenom lovu unutar Lovačkoga društva usporedila sam s podacima iz djela Jarebica (2005.) koje je izdala Lovačka udruga Jarebica Senj.

\section{NAČINI LOVA}

$\mathrm{N}$ a području Krivoga Puta divljim se životinjama prišuljavalo, postavljale su im se zasjede (zamke, stupice, čeke) ili se na njih organiziralo hajke.

U prvoj polovici 20. stoljeća, kada je na obroncima primorske strane Velike Kapele živjelo mnogo ljudi i domaćih životinja, dogovorila su se nekolicina muškaraca (od četiri, pet do tridesetak), te su išli goniti životinje. Tijekom jeseni i zime najčešće se lovilo vuka i risa budući da su u hladnijim mjesecima prilazili kućama u potrazi za hranom, te medvjede u lipnju i srpnju kada su dolazili jesti ljetinu, brati zrelo voće kojeg je ionako bilo jako malo, uzimati med iz košnica i sl. U Veljunu sam zabilježila prisjećanje na osobno sudjelovanje u takvim hajkama: Tjerali smo vukove, odi za njima gore u šumu, većinom bi u jesen dolazili. Nadi kakvih kanata, pa lupaj neke pleje, poklopce, kante i viči. Uzmi sikire i lupaj u stablo. Ljudi reci tada: Odoše u ajku! Nije bilo posebnih sprava za plašenje životinja jedino plaši s bukom. ${ }^{3} \mathrm{U}$ hajku se išlo pješice. Da bi se brže hodalo zimi su se na noge stavljale mamuze za led i snijeg ili skije. Stavi skije pa tjeraj životinju, ona ne može brzo jer propada u snig, onda ju je najlakše ulovit, onda ju zatuci sikirom. Tako se najviše lovilo veprove i prasce, pratiš tragove, no to se radilo u davnini, kazao je Ante Prpić Rus iz Mrzloga Dola. Ova su pomagala uglavnom izrađivali svatko sebi ili spretniji suseljani ostalima. Prilikom gonjenja sa sobom su vodili jednog ili dva psa. Lovci su pse vodili sa sobom i prilikom odlaska u lov na pojedine životinje, primjerice jazavce. Jazavcima se najčešće prišuljalo. Jedno drugo sjećanje na lov iz Mrzloga Dola svjedoči o tome kako su psi bili dobro dresirani te kako su sami ulovili jazavca, odnosno pronašli ga i izvukli iz rupe u kojoj je životinja boravila. ${ }^{4}$ Psi su se također koristili za gonjenje vuka, medvjeda, risa i kune. Hajke su se prestale prakticirati paralelno sa smanjenjem broja stanovnika, počevši od druge polovice 20. stoljeća. Ni u jednom lokalitetu nije zabilježeno gonjenje divljih životinja pomoću konja, kao ni ptica.

\footnotetext{
Milan Krmpotić Zekonja, Veljun.

4 Milan Pavelić Sikirica, Mrzli Dol.
} 
U svim se ispitanim lokalitetima za životinje postavljala zasjeda, odnosno čeka. Zasjeda se postavljala za divlje svinje na kaljužištima (jama s vodom u kojoj se svinje kaljužaju tj. valjaju) i za vukove. Čeke su bile odignute od zemlje, a razlog tome objasnio je kazivač iz Podbila: Životinja ima njuh, ona gleda. Ako ste na zemlji primijetit će vas, ako ste odignuti ona će doći (...) od drveta sačinjene, na svakoj strani je bila škulja (otvor op.a.) kroz koju bi lovac gledao. ${ }^{5}$ Pored čeke stavljala se meka (mamac op.a.). Isti kazivač dodao je: Meku smo mećali, ako što krepa ovca ili što. Zabiješ to kolcem u zemlju da ga ne odvuče, onda tamo čekaš. Kad dođe, ubiješ ga s puškom. Meke su se stavljale ciljano za određenu životinje, tako su kune mečili (mamili) ribom, a divlje svinje kukuruzom i na kaljužište. Noću su životinje mamili svjetlom, uglavnom džepnom lampom, a posljednjih tridesetak godina i reflektorom. Tijekom dana boravilo se na čeki i čekalo životinju. Nakon što se životinja pojavila pucalo se puškom, a po noći se zavezao konop od meke do puške. Nakon što je životinja trznula meku puška je sama okidala.

Prilikom prišuljavanja, kao i prilikom zasjede lovci su se maskirali. Zimi su odijevali svijetlu i/ili bijelu odjeću ili su se prekrivali bijelim tkaninama, uglavnom plahtama. Ljeti su odijevali odjeću zelene boje, a u jesen smeđe i šareno. No Krivopućani su isticali da je bila neimaština i da su najčešće odijevali odjeću kakvu su imali, te da je maskiranje bilo jedino ljeti i u jesen, kada su pred sebe stavili granu bogatu lišćem.

Upotreba vatre za gonjenje zvjeradi nije zabilježena. Međutim, pomoću vatre i dima na svim su ispitanim lokalitetima lovili životinje koje žive u rupama i dupljama, dakle jazavce, puhove i kune. Svi su kazivači znali objasniti kako se love puhovi. Jednostavnost postupka zrcali se u kazivanju Petra Tomljanovića Čone iz Podbila: Nade se stara krpa, namoči sa uljem, zapali i stavi u rupu. Onda životinja pobiže van pa ju se zatuče s kolcem ili čim, jer nije bilo oružja.

Sjekire su se koristile za lupanje o drveće prilikom hajke na divlje životinje te prilikom izravnoga usmrćivanja životinje, kako je zabilježeno u Veljunu: Čekaj jazavca pa kad naide, jer on ide pomalo, pa ga lupi sikirom u glavu. ${ }^{6}$

Strijele i praćke upotrebljavala su djeca, kako kazivači ističu, više za igru nego za lov. Praćke su izrađivali tako da se odrezao prirodno rašljasti komad drveta na koji se pričvrstio komad kože. Lov pomoću bodvi nije zabilježen na području Krivoga Puta.

U svim ispitanim lokalitetima kopane su jame s namjerom da u njih upadne životinja, primjerice vuk, divlja svinja, ${ }^{7}$ lisica ili jazavac. Izgled i veličina jama ovisila je o tome koju se životinju namjeravalo uloviti. Dubina jama bila je od jednog do dva metra, širina od pola do jednog metra, odnosno koliko je predviđena širina životinje kako se životinja ne bi mogla okrenuti i pobjeći van. Otvor jame zamaskirali su s daščicama, granama i šušnjem (lišćem). Na jamu u kojoj se željelo uloviti vepra nasulo se malo sitnoga krumpira da se njime privuče životinja. ${ }^{8}$ Za divlje svinje odnosno veprove na dno su jame stavljali zašiljene drvene i željezne kolce, no najčešće priručne rozge (oblik vila). ${ }^{9}$ Za vukove, lisice i kune na dno jame stavljala su se željezna gvožda (vrsta zamke na sklapanje) čija je veličina također ovisila o tome koja se životinja željela uloviti.

Svi kazivači znali su objasniti lov pomoću gvožda. Jedan od primjera slikovitih opisa je sljedeći: Gvožde čapi nogu i ne može zvir pobić ća. Onda bi vuk znao vijat. Onda čovik ču to, pa odi tamo i ubij ga. ${ }^{10}$ Uhvaćenog avuka u jami najčešće se ubijalo puškom, dok su divlju svinju zatukli sjekirom ili kolcima. Kazivači su isticali da je životinja, ako se nabila na kolce, najčešće već bila mrtva kada bi ljudi došli pa takve radnje nisu bile potrebne. Za ubijanje tupim oružjem trebala su najčešće dva do četiri snažna muškarca. Trebalo je također

\footnotetext{
Petar Tomljanović Čona, Cupići.

Milan Krmpotić Zekonja, Veljun.

Jedino je Milan Krmpotić Zekonja (Veljun) naglasio da u prvoj polovici 20. stoljeća nije bilo divljih svinja. Razlog tome možemo pronaći u podatku da divlja svinja u lovište dolazi u većem broju kada u Primorju rodi žir ili kada su zime sa dubokim i dugotrajnim snijegom u zaledu Velebita. (Jurčenko et al. 2005:42)

8 Prema kazivanju Ivana Krmpotića Bokule, Veljun.

9 Opis rozgi vidi u prilogu o zemljoradnji, kod M. Rajković u ovoj monografiji.

10 Milan Krmpotić Zekonja, Veljun.
} 
snage da se divlja svinja izvuče iz uske jame duboke oko dva metra. Za taj postupak divlju svinju ovezali su konopcima te su je pomoću njih izvlačili van. Ovakve jame nisu kopali na područjima gdje je zemlja bila tvrda, nego uglavnom na nižim nadmorskim visinama (Primorje) budući da ih je bilo teško kopati.

Na svim ispitanim lokalitetima zabilježen je lov pomoću petlji koje su životinju stezale oko vrata. Petlje su, odnosno kako ih Krivopućani nazivaju sajle, ${ }^{11}$ omče, ${ }^{12}$ žičana zamka, ${ }^{13}$ bile raznih veličina ovisno o životinji za koju su bile namijenjene (vidi sl. 2, preslika UEA, br. 1, str. 110, sl. br. 2). Budući da su se lako izrađivale, radili su ih pojedinci sami od mekane, tj. savitljive žice. Najčešće je to bila polučelična žica promjera oko 0.8 milimetara, no debljina i jakost žice ovisile su o tome koja se životinja namjeravala uloviti. Na taj su se način lovili zečevi, lisice, jazavci, kune i vukovi. Odrastajući na marginama šume, dječaci su imali prilike promatrati kuda se životinje kreću, naučiti prepoznavati njihove tragove i vrijeme kada je koja životinja kuda prolazila i provlačila se te su ciljano postavljali petlje i zamke. (vidi sl. 2, preslika UEA, br. 1, str. 110, sl. br. 5). Tako se primjerice zamku za zeca najčešće stavljalo u okolicu kupusa, a za jazavca i kune na prolaz odnosno otvor rupe u kojoj borave. Pored petlji, omči, postojale su petlje koje se zatežu pomoću pruta ili mladog drveta. (vidi sl. 2, preslika UEA, br. 1, str. 110, sl. br. 4) Takvi su se postupci odvijali na način da se savije neka grana na prolazu gdje prolaze životinje, recimo gdje zečevi imaju svoju stazu, ako ne, napravi se umjetna. Omča stoji. Čim omča počne stezat zec trči naprijed, to ga sve više steže i on je gotov. Sam sebi zategne vrat $i$ udavi se. ${ }^{14}$

U današnje vrijeme lovočuvar Milan Tomljanović Livak iz Bunice pronalazi ovakve oblike zamki po šumi. Tako je naveo slučajeve koji su se zbili u lipnju i srpnju 2003. godine kada je pronašao tridesetak zamki na području od petstotinjak kvadratnih metara. To su bile neke žice, sajlice, oke mi to zovemo. Njih više bilo je vezano za drvo, medusobno su bile povezane. Bile su namijenjene za lov srna, vepra, lisica,... zapravo zavisi u kojoj visini su postavljene. Ako su postavljeno malo više na jedan metar, onda je za srneću divljač, a ne oko $20 \mathrm{~cm}$ od zemlje je za lisicu i zeca, pa što se ulovi. Nakon što se noči krivolov počinitelji se pokušaju uhvatiti na djelu. Ako ne, zamke se uklone.

Krivopućani su poznavali zavidno velik broj stupica koje bi poklopile životinju. Pod kamenu ploču odnosno škrilj najviše su se lovile jarebice i to na području Primorja (Bunica, Sibinj, Sv. Jelena, Sv. Ilija, Špalji), odnosno u nižim predjelima uz obalu, budući da jarebice ne žive na visokim nadmorskim visinama. Kamena je ploča bila dimenzija 50 puta 50 centimetara ili manja. Takav komad kamena obično se pronalazio u šumi i bio je neobrađen. Kazivači su napominjali da se moralo paziti da ploča ne bude preteška i da ne prignječi životinju budući da tada meso ne bi bilo upotrebljivo. Lovilo se na način da se pod jednu stranu ploče podmetnuo drveni kolac ili rašlje. Ispod se nasipalo žita koje je trebalo privući jarebicu. Kada je ptica došla ispod, ploča ju je poklopila. Druga mogućnost bila je zavezati konop na rašlje i čekati na udaljenosti od oko 20 metara, kada bi jarebica došla ispod ploče čovjek je povukao konop i ploča je pala na pticu. (vidi sl. 2, preslika UEA, br. 1, str. 110, slika br. 6) U svim je ispitanim lokalitetima zabilježen lov ptica pod sito. $\mathrm{Na}$ taj su način, uglavnom djeca, lovila ptice najčešće tijekom zimskih mjeseci. Također, najviše se lovilo na području Primorja i na područjima koja su na nižim nadmorskim visinama i bliže obali jer, kako kazivači navode, ondje ima najviše ptica. Josip Prpić Jurina iz Mrzloga Dola na ovakav je način lovio ptice kada je bio dječak: Metni sito i zaveži ga špagom. Metni jednu rašljicu ispod. Jedan kraj sita je bio u snijegu, a hrana unutra, naspi žita, a šojka (vrsta ptice op.a.) bi došla unutra i jela (...) potegni špagu i uhvatiš je. Imali smo ukras perja od šojke. Neke bi pustili. Ptice su također lovili u kutije, u koje su prethodno nasuli žitarice. ${ }^{15}$

11 Veljun, Francikovac.

12 Mrzli Dol, Podbilo.

13 Podbilo, Alan.

14 Objasnio je Josip Prpić Jurina, Mrzli Dol. Isto su potvrdili svi kazivači.

15 Objasnio je Ante Prpić Rus iz Mrzloga Dola i pokazao sliku u Upitnici EA, br. 1, str. 110, slika 8. 
Lov kuna bjelica i zlatica, lisica te, rjeđe, puhova, pomoću kladica zabilježen je također na svim ispitanim lokalitetima. Kladice su bile napravljene od dva neobrađena drveta, najčešće bukve ili jele. Veličina kladica također je ovisila o tome koju životinju se namjeravalo uloviti. Najveće su kladice bile za kune, duge oko dva do tri metra, promjera oko desetak centimetra. Zamka se postavljala na način da je jedno drvo bilo gore drugo dolje, između se stavljao komad drveta u obliku rašlja ili manja žica u obliku federa koji je imao ulogu držati gornju kladicu. U taj se prostor stavljao mamac odnosno meka: ocvirak (komadić, rub, op.a.) slanine, kost, uginulu pticu, miša, jaje. Za meku se koristio i termin ješka. Kada je životinja hodala po donjoj kladici pomaknula bi rašlje, odnosno potegnula ješku te ju je gornja kladica poklopila. (vidi sl. 2, preslika UEA, br. 1, str. 110, sl. br. 9) Kune se moralo privikavati na mamce, tako da se životinju počinjalo mečit u rujnu. Nakon što je pojela nekoliko mamaca, ona se navikla, tj. namečila te ju je bilo lakše uloviti u studenome. Naime, u studenome je bilo razdoblje lovljenja kuna, budući da im je tada najkvalitetnije krzno. Na ovaj su se način kune lovile do 70-ih godina 20. stoljeća.

Na području Krivoga Puta kune, lisice i zečevi lovili su se i pomoću tulaca. Tulcem Krivopućani nazivaju rupu u ilovači od 70 do 80 centimetara duboku ili smotan pleh iste duljine u koji bi također stavili ješku. Kuna je unutra ušla naglavačke i nije više mogla izaći van. Lov kuna pomoću tulca vidljiv je u kazivanju Josipa Prpića Jurine iz Mrzloga Dola: Taj čovik bi znao gdje će kuna ući u svoje sklonište, a mali izlaz je imala kud je izlazila van, sad je on tu napravio jedan tzv. tulac i tu je bio probijen. Odozgo bi metnuo drvo, $i$ kad bi isla van, drvo bi pogurnula, a ovo bi palo po njoj. Ako bi bila kuna zlatica, to je bio dobar lov, krzno se dobro prodavalo. ${ }^{16}$ (vidi sl. 2, preslika UEA, br 1, str. 110, sl. 10) Lov na način da se spuštaju vrata zabilježen je samo na području Podbila.

Na području Podbila, Veljuna i Mrzloga Dola radili su se $u$ davnini torovi za ulov vuka. Kazivači iz ovih lokaliteta nisu znali kojih su se godina radili ovakvi torovi, odnosno za vrijeme njihova života oni se nisu radili već su o njima čuli od roditelja i sumještana. Kazivači iz ostalih ispitanih lokaliteta, posebice u Primorju, dakle naseljima na nižim nadmorskim visinama, samo su čuli da se takvi torovi izrađuju no smatraju da se oni nikada nisu radili u Primorju. U svim lokalitetima ovakve torove nazivaju pletarice i ruska klopka. Klopka je bila okrugloga oblika, promjera oko četiri metra. Imala je dupli uski hodnik, poput tunela širine vuka. Bila je napravljena od kolaca, grana i letvica visine od 60 centimetara do jednog metra, koji su bili poslagani jedan do drugoga. (vidi sl. 2, preslika UEA, br. 1, str. 110, sl. 13.) Odozgo se pokrilo kolcima na koje se stavilo janje koje je blejalo i tako prizivalo vuka. Na području Podbila janje se stavljalo u sredinu tora: Vuk bi doša, kružia, iša unutra prema janjetu, a vrata bi se zatvorila kada bi on uša unutra (...) bilo je slučajeva di nije bilo vrata onda bi on gad izaša u rikverc van, pametan je on, objasnio je jedan od najstarijih kazivača, Marko Pavelić Mijatina iz Podbila, rođen 1917. godine. Ulovljenog vuka usmrtilo se puškom.

Najčešći način lova na cijelom ispitanom području je lov pomoću gvožda. (vidi sl. 2, preslika UEA, br. 1, str. 110, sl. 15) Na gvožda su se lovile lisica, zec, divlja svinja, jazavac, kuna, divlja mačka, jelen te vuk. Veličina gvožda ovisila je o tome koja se životinja želi uloviti. Mala gvožda promjera oko 15 centimetara koristila su se za lisice i zeca. Velika gvožđa, promjera oko 20 do 30 centimetara, bila su za veprove, tj. divlje svinje, jelene i vukove. Gvožda su bila okruglih i četvrtastih oblika. Nakon što se zamka postavila na zemlju, morala se zamaskirati travom i lišćem te se na nju stavio mamac. Za lisicu su iznad gvožda objesili živu kokoš ili su stavljali komadiće mesa. Čitav postupak morao se raditi u rukavicama jer životinja osjeti ljudski miris $i$ onda ništa od ulova, ${ }^{17}$ napominjali su moji sugovornici. Za lisicu se stavljalo više mamaca, primjerice nekoliko komadića kože budući da je lisica lukava i neće uzeti ako je jedan mamac, a ako ih je više neke uzme, a neke ostavi. Stoga se za lisicu osim više mamaca postavljalo i nekoliko gvožda. Gvožde se s lancem, dugim oko jednog metra na čijem se kraju nalazilo sidro, učvrstilo ili zavezalo za drvo jer bi u

16 Isti postupak objasnili su svi kazivači.

17 Francikovac, Veljun, Mrzli Dol, Šojatski Dolac. 
protivnom uhvaćena životinja odnijela gvožde. Krivopućani se prisjećaju više slučajeva kada su lisica i vuk uhvaćeni na gvožda sami sebi pregrizli nogu i otišli. ${ }^{18}$ Budući da je lov s gvožđima krivolov, ona se nisu mogla kupiti te su ih pojedinci naručivali kod kovača, a poneki i sami izrađivali. Lovočuvar Lovačkoga društva Milan Tomljanović Livak iz Bunice napominje da se ljudi u današnje vrijeme time više ne bave i da on tijekom svog radnog vijeka kao lovočuvar nije ni jedna našao na lovištu.

Životinje se nisu lovile bacanjem kamenja, osim kada su djeca bacala kamenje na vjeverice. Štapovi, odnosno palice, koristile su se prilikom istjerivanja životinja koje žive u dupljama, ponajviše puhova iz drveta. Kijače za bacanje nisu se koristile, kao ni grane za patke budući da na ovom području patke ne žive. Na području Krivoga Puta nije se lovilo ni pomoću samostrela. Na čitavom području nije zabilježen lov razapetim mrežama, vršama niti udicama. Jedino je Milan Pavelić Sikirica iz Pavića vidio kako se lovi kos na bisak odnosno ljepilo koje se stavi na grančicu, ali navodi kako se tako lovi na nižim nadmorskim visinama, u Primorju. Na ostalim lokalitetima takav oblik lova nije potvrđen.

\subsection{PUHOVI}

Duhove su lovili u svim lokalitetima, kako odrasli Krivopućani tako i djeca. Puhovi žive u drvetu, u 1 leglu od pet, šest do desetak i više komada. Prolazeći šumom lovci su tražili drveće na kojem je bila rupa te oko kojega je bilo puhova izmeta, što je bila potvrda da tu žive puhovi. Nakon što se lociralo stablo puhove su vadili van gurajući ih na drugu stranu otvora. Obitavališta puhova imala su najčešće dva otvora, na početku i na završetku rupe duge oko jednoga metra. Ako je rupa bila manja, u nju su gurali štap od lijeske (u Lucićima zvan i gurać) ili bilo kakvu granu, naveli su u ostalim lokalitetima. Puh se branio i izlazio van na drugi otvor. Kada je izvirio glavom lovac ga je pritisnuo šipkom, uzeo za vrat $i$ lupio mu glavom u stablo jer, kako kazivači napominju, trebalo se paziti jer on grebe i grize. ${ }^{19} \mathrm{Na}$ taj su način iz drveta izvlačili jednog po jednog puha, dok svi nisu izašli. Drugi način istjerivanja puhova iz drveta bio je pomoću baklji koje su se stavile u njihovo duplje. ${ }^{20}$ Ante Prpić Rus iz Mrzloga Dola vidio je i lovljenje puha u zamku koja bi se izradila u obliku kutije, unutra bi se stavio mamac i nakon što je puh ušao vrata bi se zatvorila. Isti kazivač je ovakav oblik zamke usporedio sa slikom br. 11. (vidi sl. 2, preslika UEA, br. 1, str. 110)

Niti u jednom ispitanom lokalitetu kazivači nisu čuli za naziv polhove niti da se time love puhovi. Puhovi su bježali od vatre i dima. Nakon što su izašli van, postupak je bio isti. Josip Prpić Jurina iz Mrzloga Dola prisjetio se svojih iskustava iz mladosti: Sabirali smo ih od 10 do 20 do navečer. Nosi kući, opali ga (spali dlaku op.a.), raspravi ga (izvadi iznutrice op.a.) i meći na tavu. Kila puhove masti je bila 12000 dinara. To je bio kapital. Bila su dva brata, oni su svaki dan lovili najmanje po 40 komada puhova. Mast je jako zdrava za sve rane. Mi smo samo jeli.

Puhove su zbog prehrane najčešće lovili dječaci prilikom boravka na paši s domaćim životinjama, gdje su ih uglavnom i pripremali i konzumirali. Puh se mogao pripremiti na dva načina: Može se oderat koža, skinut koža, a može se zapalit dlaka i onda se ta kožica skine rukama ne treba nožem. Onda se izvadi trbuh, iznutrica, očisti se i može se peć na ražnju ili na mast. ${ }^{21}$ Kazivači su isticali da je puhova bilo jako puno dok nisu prorijedili šume. Naime, oni su boravili u dupljama u starim stablima. Isticali su također da je od svih životinja puh najčišći, budući da jede voće i šumske plodove, posebice jagode i žir, a od domaće hrane žgance (palentu) i kruh. Moji su sugovornici često prilikom razgovora isticali da se na ovim područjima teško živjelo, da nisu imali dovoljno hrane, posebice mesa. Tako sam u Mrzlom Dolu zabilježila priču

\footnotetext{
18 Podbilo, Alan, Krivi Put, Mrzli Dol, Francikovac, Veljun.

19 Milan Krmpotić Zekonja, Veljun; Milan Blažević Ivela, Mrzli Dol; Josip Prpić Jurina, Mrzli Dol; Marko Prpić Rus, Mrzli Dol; Milan Šojat Colaš, Francikovac; Petar Šojat Budić, Šojatski Dolac; Ivan Tomljanović Rokin, Vrataruša; Milan Tomljanović Periša, Alan.

20 Petar Tomljanović Čona, Podbilo. Isto su potvrdili svi kazivači.

${ }^{21}$ Vidljivo iz naracije Milana Blaževića Ivele iz Mrzli Dol. Ova dva načina pripreme puha opisali su svi Krivopućani.
} 
o dva brata iz Lucića koji su bili jako siromašni te im je glavno meso u prehrani prema kazivanjima, sa zastupljenošću od čak $90 \%$, bilo puhovo. Kad su išli kroz šumu, a to je bilo gotovo svakodnevno, kući su donosili po desetak puhova. Susjedi su kazivali da će puhovi slavit kad Marko umre, da će reč: Slava mu! ${ }^{22}$ budući da ih je on najviše lovio. Osim za osobne potrebe, Krivopućani su ulovljene puhove prodavali. Dok je pojedinim kazivačima puhovo meso ukusno i fino, te su navodili da ih i danas znaju uloviti i jednog do dva radi želje speći i pojesti, većina ih s gađenjem gleda na njihovu konzumaciji te navodi kako ih nikada ne bi jeli budući da izgledaju kao štakori.

Osim za prehranu, Krivopućani su puhove lovili za izradu ljekovite masti. Njihova mast koristila se za uspješnije i brže zacjeljivanje rana te za liječenje reumatskih promjena u zglobovima, posebice u koljenima. ${ }^{23} \mathrm{Za}$ kvalitetnu mast najbolje je bilo uloviti puha u jesen, budući da su tada bili najdeblji, odnosno moglo se dobiti najviše masti. Mast se radila tako da se puhu ogulila koža ispod koje se nalazio red slanine. Slanina se ogulila i topila u padelici (zdjelici op.a.). Istopljena mast spremala se u bočice i koristila čitavu godinu.

\section{OPHODI S VUKOM}

$\int$ edror edna od najvažnijih gospodarskih grana Bunjevaca na primorskoj strani Velike Kapele svakako je bilo stočarstvo. Domaće životinje vodilo se isključivo na dnevne ispaše ${ }^{24}$ ponajviše iz razloga što ih se bojalo ostaviti vani preko noći zbog vukova. Kazivači su isticali da vukovi, medvjedi, risovi, kao i ostale divlje životinje, dolaze do samih kuća kako na višim planinskim predjelima tako i nižim. Vukovi su prilazili ljudima i odnosili im manje životinje, najčešće ovce i koze. Znalo se dogoditi i da skupina vukova napadne junicu. Kazivač iz Veljuna naveo je da je najviše vukova bilo iza 1945. godine te se prisjetio nimalo ugodnoga događaja iz istog razdoblja kada je on čuvao blago, a oko njega je došlo dvanaest vukova, no na sreću nisu valjda bili gladni već su samo kružili oko njega i ovaca. ${ }^{25}$ Vukovi su često napadali ovce. Nerijetko bi, ako su psi bili s ovcama i branili ih od vukova, rastrgali i psa.

Upravo je iz ovih razloga ubojstvo vuka bio ponos te se u nekim lokalitetima ono obilježavalo ophodom selom, ophodom nekoliko sela, ali i šireg područja. ${ }^{26}$ Krivopućani su isticali da je o svakom pojedincu ovisilo hoće li obilaziti s vukom i koliko područje. Stanovnici Veljuna te većine sela na području Mrzloga Dola nisu obilazili selom jer prema kazivanju iz Lucića: Ovde se znalo. Ako je recimo Joso Prpić ubio vuka, to se znalo sve do Senja dole..$^{27} \mathrm{U}$ ophode s vukom na područje Krivoga Puta najviše su dolazili Podgorci, koji su i inače navikli prosit objasnili su kazivači, te dodavali da je prije život bio težak i da je svako gledao pronaći način kako da nešto dobije. ${ }^{28}$

Izgled vuka kojim se obilazilo selo imao je nekoliko varijanti. Milan Pavelić Sikirica iz Pavića sjeća se da se čitav vuk nabio na kolac i nosio. Na području ostalog Mrzloga Dola i Podbila nosila se oderana vučja koža, nije se rezala po drobu (trbuhu op.a.) već kao da ju svuku. ${ }^{29} \mathrm{U}$ kožu se stavljalo slame ili šušnja (suhog lišća op. a.). Na taj je način vuk na kolcu izgledao kao pravi, ali je bio lagan za nositi. Na Veljunu

\footnotetext{
Milan Blažević Ivela, Josip Prpić Jurina, Ivan Prpić Kavarica, Mile Prpić Popić svi iz Mrzlog Dola.

Detaljnije vidjeti u prilogu o narodnoj medicini autorice P. Kelemen u idućem svesku Monografije.

Detaljnije vidjeti u prilogu o stočarstvu autorice M. Rajković u ovoj monografiji.

Milan Krmpotić Zekonja, Veljun.

26 Primjerice iz sela Senjske Drage (Žuklja, Ljubežina, Liskovc) do Veljuna, Mrzloga Dola, iz velebitskog Podgorja (posebice sjevernog i srednjeg Velebita, dakle i do dvadesetak kilometara) do Veljuna, Francikovca, Klaričevca.

27 Milan Blažević Ivela, Mrzli Dol. Isto su potvrdili svi kazivači.

28 Ivan Krmpotić Bokula, Mara i Luka Krmpotić Brndini, Anka Butković Matićeva, Mica Komadina Marićeva, Marija Rončević Garina, Krunoslav Krmpotić Econja, Mara Tomljanović Isanova, Mira Tomljanović Ropetina, Marko Pavelić Mijatin, Branko Tomljanović Ropeta.

29 Marko Pavelić Mijatin, Anka Šolić Tutanova, Petar Tomljanović Šimaica, Milan Blažević Ivela, Josip Prpić Jurina.
} 
je zabilježeno nošenje oderane vučje kože koja se raskrilila samo nako na kolce. ${ }^{30} \mathrm{U}$ ophod selom išla su dva do tri muškarca. Ulazili su u svako dvorište i pritom izgovarali određene stihove, primjerice:
Dajte vuku vunice da ne kolje junice. ${ }^{31}$
Dajte vuku slanine da ne dere planine. ${ }^{32}$
Dajte vuku slanine neka beži u planine!
Dajte vuku slanine, da ne jede bravine.
Dajte vuku mesa, da tovar ne pritresa. ${ }^{33}$
Dajte vuku mesa da ne pretresa. ${ }^{34}$

Nakon što bi otpjevali pjesmu, domaćini su ih počastili i darivali. Krivopućani su darove davali kako je ko moga. Obično se poklanjalo slanine, mesa, jaja, vune, novaca, nešto za popiti, počastilo ih se hranom. No bilo je i ljudi koji nisu imali ili nisu željeli dati, te nisu dali ništa. Od sakupljenih darova kasnije se napravilo slavlje ili su ih nosioci vuka podijelili između sebe. Ako su vuka ubili stanovnici s području Mrzloga Dola, također su obilazili s vukom, ali istaknuto je kako nisu uzimali poklone, već to se tako išlo da se zna da su ga ubili. ${ }^{35} \mathrm{Ni}$ u jednom lokalitetu Krivopućani nisu imali naziv za ovaj ophod kao ni za ljude koji su nosili vuka, osim na području Veljuna gdje su kazivači čuli naziv bušari. ${ }^{36}$

Posljednji su ophodi vukom na ovim područjima zabilježeni u Mrzlome Dolu i Veljunu oko sredine 20. stoljeća kada su dolazili Podgorci. Na ostalim lokalitetima za vrijeme života kazivača nisu postojali takvi ophodi, već su im o njima pričali stariji ukućani i sumještani. Šezdesetih i sedamdesetih godina 20. stoljeća država je davala naknadu osobi koja je ubila vuka. Svi kazivači znaju da su danas vukovi zaštićene životinje i da se ne smiju ubijati. Ovakav zakon ne sviđa se stanovnicima viših nadmorskih visina koji žive u blizini šuma kao primjerice na Alanu, Krivome Putu, Mrzlome Dolu i Francikovcu budući da vukovi dolaze u blizinu kuća, posebice ljeti kada su žedni, a i zimi kada su gladni. Tijekom našeg boravka na terenu u lipnju 2005. godine nekoliko je vukova primjerice došlo u dvorište obitelji Prpić Jurine u Mrzlome Dolu i napalo psa. Krivopućani su često govorili: Više se ne boje, sada se mi opet bojimo njih.

\section{TRADICIJSKI LOV KAO DIO TRADICIJSKOGA GOSPODARSTVA}

$\mathrm{O}$ sim primarnih gospodarskih grana poput stočarstva i zemljoradnje te glavnih dodatnih izvora prihoda, odlaska muškaraca na privremene i sezonske radove, tradicijski lov u prvoj polovici 20. stoljeća možemo promatrati kao nadopunu tradicijskim oblicima gospodarskih djelatnosti sve do raseljavanja stanovništva s ovih područja. Unatoč tome što su moji kazivači bez susprezanja, čak s ponosom, navodili kako su nadmudrivali divlje životinje, a zatim ih ubijali hladnim oružjem, isticali su da niti jednu životinju nisu lovili zbog zabave niti trofeja već zbog neimaštine, prvenstveno zbog nedostatka hrane, gladi, prodaje kože kao izvora prihoda te pravljenja ljekovitih masti. Stoga ću u narednom odlomku prikazati razloge lova pojedinih životinja.

30 Mara i Luka Krmpotić Brndini, Jula i Krunoslav Krmpotić Econjini, Mara Tomljanović Isanova, Veljun.

31 Mrzli Dol.

32 Veljun.

33 Ivan Krmpotić Bokula.

34 Veljun.

35 Istaknuo Milan Pavelić Sikirica, Mrzli Dol.

36 Luka i Mara Krmpotić Brndini, Veljun. Isto su potvrdili: Anka Butković Matićeva, Mica Komadina Marićeva, Marija Rončević Garina, Alan; Krunoslav Krmpotić Econja, Veljun; Mira Tomljanović Ropetina, Krivi Put; Draga i Marko Tomljanović Rilčevi, Mrzli Dol; Marko Pavelić Mijatina, Podbilo. 


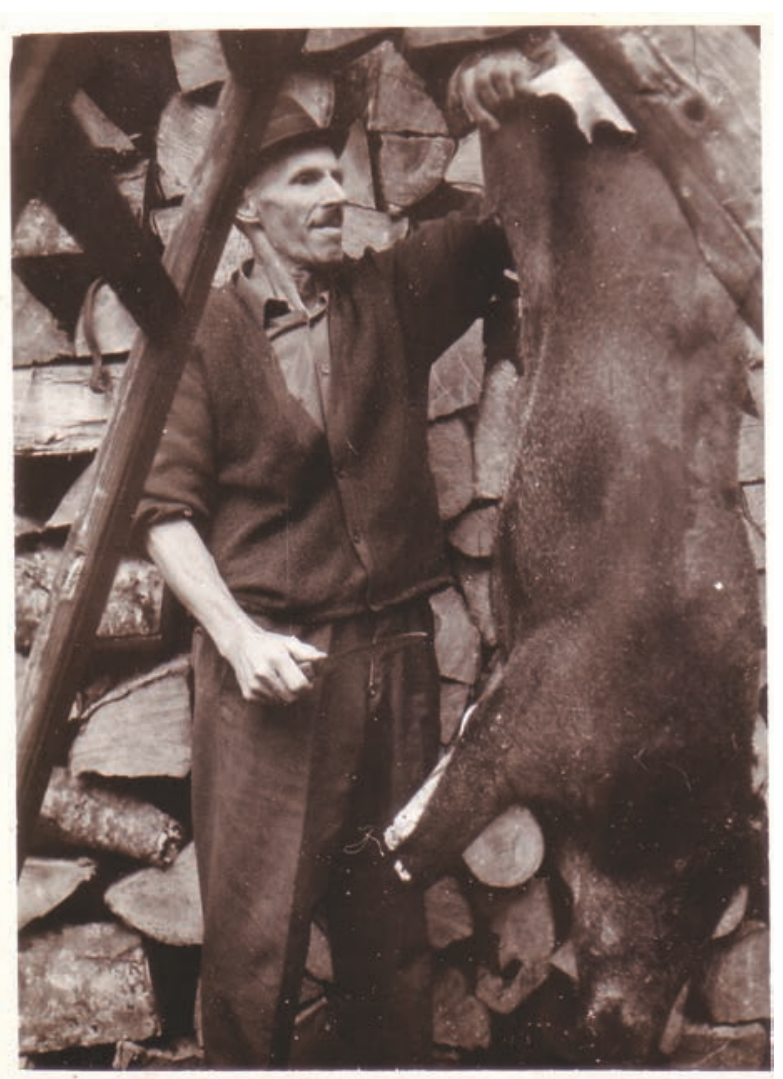

Slika 3: Petar Tomljanović Pešo s divljom svinjom 1968. godine, Krivi Put; snimatelj nepornat.
Jazavac se lovio zbog mesa, izrade ljekovite masti, ${ }^{37}$ kože te pravljenja masti za mazanje predmeta od metala. Lisica se lovila ponajviše zbog krzna. Naime, do prije 20-ak godina njezina se koža otkupljivala u Senju. Osim toga, kazivači su isticali da je ona štetočina i da je nerijetko znala doći u kuću ako se ostave otvorena vrata, te po noći u štalu i kokošinjac i zaklati sve kokoši. ${ }^{38}$ Divlja svinja, odnosno vepar lovio se zbog mesa koje se pripravljalo i konzumiralo kao i od domaće svinje (sl. 3). Dakle, meso se pripravljalo svježe, dimilo se, a ako je svinja bila velika radili su i kobasice, no to je ipak bilo iznimno. No lov na ovu životinju bio je rijedak budući da ih nije bilo puno. Kazivači su govorili da divljih svinja nije bilo dok je bilo vukova, odnosno kada je nestalo vukova pojavile su se divlje svinje. Nakon dolaska divljih svinja povećao se broj srna i jelena. Tu nitko nije vidio jelena dok je bilo vukova, jer velike su tu zime $i$ snijeg a za jelena je to propast, on propada po snijegu. ${ }^{39}$

Srne i jeleni lovili su se zbog mesa. Divlja mačka i ris lovili su se zbog krzna, mesa i masti. Kuna zlatica i bjelica lovile su se zbog kože koja se otkupljivala u Senju i bila znatan izvor prihoda.

Koža kune zlatice je primjerice iza Drugoga svjetskog rata bila tako skupocjena da se za tri kože moglo kupiti dva vola, a za jednu kožu manju kravu. Kunine kože prodavale su se do unazad 25 godina otkupljivaču iz Rijeke. Kazivači su često navodili da se nakon što bi se prodalo kuninu kožu moglo cijelu noć piti i častiti sve koji su se zatekli u gostionici, a ne bi se popila ni vrijednost kunina repa. Zeca se također lovilo zbog mesa i krzna. Sve životinje koje su se lovile zbog krzna lovile su se u listopadu i studenome budući da im je tada krzno najbolje kvalitete.

Osim lova divljih životinja zabilježeni su primjeri kada se mlada životinja dovede kući i odgaja. Tako je na Veljunu Milan Krmpotić Zekonja u šumi pronašao mlado lane: Onda sam to donio kući i daj mu mlika i hrani ga. Na jesen smo ga zaklali jer dakako ko bi ga pustia. Meso gotovo pitomo... Tako i zeca kad se kosilo nadi u livadi. Al ako je malo onda većinom ugine jer to je naućilo na majku, a ako je veći onda pobigne, obično nadi miće (male op.a.).

Mada sve ove oblike lova na divlje životinje smatramo krivolovom, oni su opstali sve dok se stanovništvo nije počelo iseljavati s planinskih područja, dakle do sedamdesetih godina 20. stoljeća. Unatoč tome što Lovačko društvo Jarebica postoji od 1930. godine, razgovarajući s lovočuvarem doznajem da ni u današnje vrijeme ne možemo izostaviti krivolovce. Upravo iz toga razloga zanimalo me zna li uopće prosječan stanovnik, dakle onaj koji nije lovac, kada su službene zabrane lova na pojedinu divlju životinju. Naime, zabrana lova određena je zakonom za svaku životinju. Kazivači su kazivali da se životinje ne smiju ubijati kada nose mlade, i to ženke, dok se mužjaci smiju ubijati te da se štetočine, poput lisica smiju

Posebice za reumatske promjene.

38 Ivan Krmpotić Bokula,Veljun. Isto su potvrdili kazivači u svim lokalitetima.

39 Anka Šolić Tutanova, Podbilo; Marko Tomljanović Rilac, Mrzli Dol; Milan Šojat Colaš, Francikovac; Ivan Tomljanović Rokin, Vrataruša; Ivan Vukelić Mikula i Milan Tomljanović Kanada, Podbilo. 
stalno ubijati. No ipak kazivači navode da što se na zamku uhvati, uhvati, nisu mogli znati hoće li to biti mužjak ili ženka i nosi li trenutno mlade.

\section{SUVREMENI LOV U SKLOPU LOVAČKOGA DRUŠTVA JAREBICA, SENJ}

$\mathrm{O}$ samostaljenjem Republike Hrvatske donesen je novi Zakon o lovu (NN 10/94, 22/94- ispravak 22/94), a time i promjene u gospodarenju lovištima. Iz odredbe članka 5. stavka 1. Zakona proizlazi da je: na načelima privatnog vlasništva, odnosno na dominalnom ili zakupnom sustavu prema kojem je pravo lova spojeno sa vlasništvom zemljišta, te pripada njenom vlasniku. Nakon raspisanog natječaja Lovačko društvo 'Jarebica' Senj dobilo je u zakup lovište broj IX/13 'Senj' (sl. 4) i državno lovište IX/17 'Sveti Juraj'. (Ibid.) $S$ ovim se promjenama lovište smanjilo.

Zbog velikoga zakupa povećala se i članarina koja je u socijalističkoj Jugoslaviji, kada je lovište bilo društveno vlasništvo, bila simbolična. U Lovačkom društvu danas se plaća društvena članarina, županijska i savezna. Osim smanjenja površine i kvalitete zemljišta, povećane su i obaveze članova. Članovi Društva, lovci, tijekom godine trebaju sakupiti više radnih bodova: stvaraju materijalna dobra, unose novu divljač, rade na vodoopskrbi, čišćenju lokava, izradi novih lokava, čeka, hranilišta. Članovi Društva kazivali su da se ono sve više bazira na prihrani i prehrani divljači nego na samom lovu, te se od lovišta pretvara u uzgojno lovište. Primjerice u lovište su 2005. godine bacili 11 tona jabuka, par tona šećerne i krmne repe. Povećanje obaveza, smanjenje lovišta i povećanje članarina, prema riječima predstavnika Lovačke udruge i lovaca, utjecale su na smanjenje broja lovaca.

Na lovištu Senj danas obitavaju: srna, divlja svinja, medvjed, zec obični, kamenjarka, divlja mačka, jazavac, kuna zlatica, kuna bjelica, lisica, tvor, šojka, vrana siva, divlji golub pećinar, vuk, ris i prepelica pućpura (usp. Jurčenko et al. 2005:37-38). No da bi se ove životinje moglo loviti najprije se mora postati članom Lovačkoga društva, a prije toga i lovcem. Lovcem se postaje nakon što se stažira godinu dana tijekom čega se prolaze faze rada unutar Društva, primjerice od izgradnje lovno-gospodarskih objekata, prihrane i prehrane životinja. Nakon obavljenoga staža osoba polaže lovački ispit $i$, ako ga uspješno položi, dobiva diplomu. Tek se tada može učlaniti u Lovačko društvo. Na pitanje zašto netko uopće želi postati lovac, sami lovci su odgovarali: biti lovac na ovim prostorima prenosi se iz generacije u generaciju, zbog ljubavi prema životinjama, ljubavi prema prirodi, volim šetat po šumi.

Lovačko društvo ima sastanke svaki mjesec na kojima se okupe članovi izvršnog odbora. Svi lovci pozvani su na godišnju skupštinu, a tijekom godine lovnici imaju slobodu sazivati sastanke. Društvo se sastoji od predsjednika, tajnika, lovočuvara, lovnika grupa i predsjednika grupa. U grupama ima od 40 do 60 ljudi i svaka grupa ima svog lovnika. Da se ne zanemari pojedino loviste lovci su podijeljeni u više grupa. Grupe su podijeljene po radnim obavezama. Teren Lovačkog društva je veliki i grani-

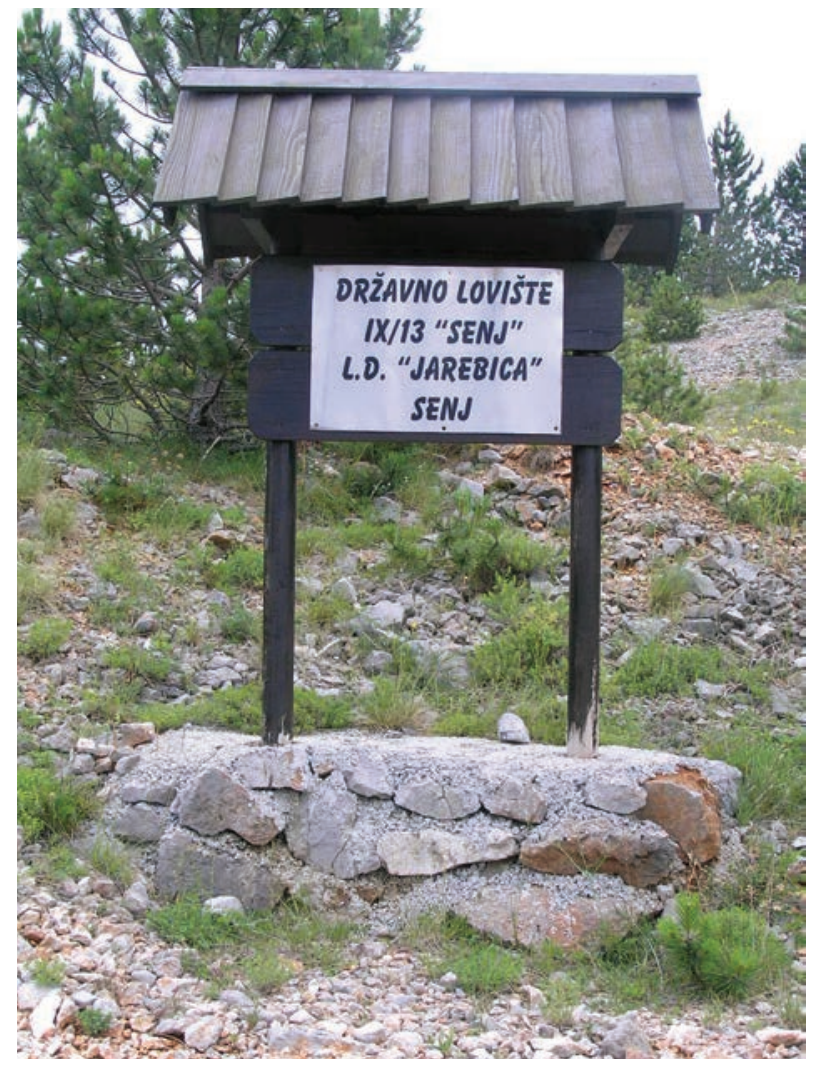

Slika 4: Oznaka područja Državnog lovišta broj IX/13

'Senj' u zakupu Lovačkog drusttva Jarebice; snimila Marijeta Rajković, svibanj 2004. 
ce imaju oko 50 kilometra. Radi se kroz cijelu godinu, a lovnici idu po lovištima vide što nedostaje signaliziraju predsjednicima grupa oni predsjedniku Društva i zatim se ide raditi, kazao je tajnik Društva Milan Vukelić Deviza. Svaki član Društva ima obaveze prema istome, a ujedno na taj način i skuplja bodove. Posljednjih godina lovci su velik trud uložili oko izgradnje Lovačkoga doma u Perdasima i gatera za divlje svinje (ograđeni dio gdje se unose divlje svinje za uzgoj, koje se nakon nekog vremena puštaju u lovište).

Sezona lova je čitavu godinu, npr. na divlju svinju mǔ̌jaka, dok se ostali lovostaji odrecuju prema razmnožavanju pojedine divljači. Primjerice za crnu divljač posebno, za plemenitu divljač posebno, za ptice. (...) Na ovom području sezona lova na crnu divljač počinje sredinom 10 mjeseca i traje najdalje do 15. siječnja, objasnio je Milan Vukelić Deviza. Sezona lova na ovom području počinje svake godine oko 15. listopada (kazivači napominju da mora biti nedjelja budući da većina članova radi ostalim danima). Na otvorenje lova prema tumačenju Milana Vukelića Devize, tajnika Lovačkoga društva, dođe stotinjak lovaca, odnosno 50 do 60 \% članova Lovačkoga društva. Danas 'Jarebica' ima 195 članova (Jurčenko et al. 2005:18). Svake godine odredi se vrsta životinje koja se lovi, a najčešće su to divlje svinje ili lisice. Lovci se nakon zajedničkog lova druže uz ručak u Lovačkom domu u Perdasima, Senjska Draga (sl. 5).

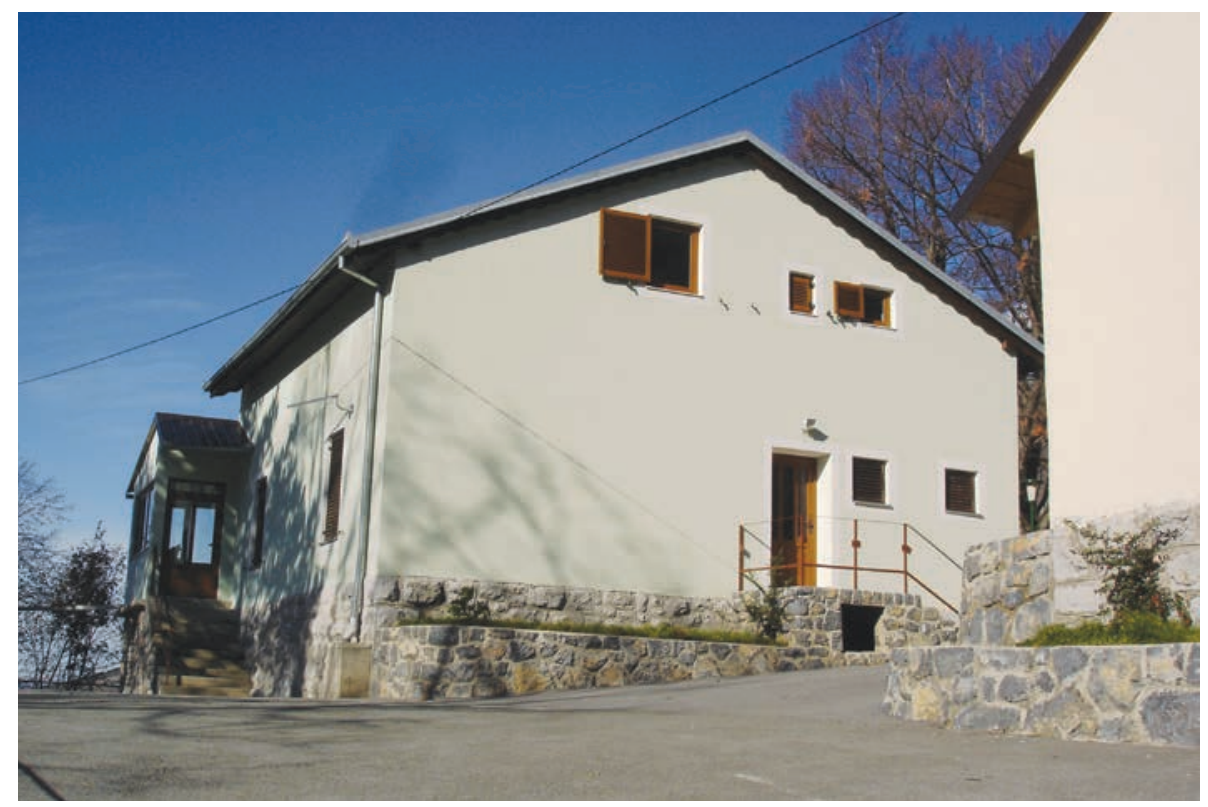

Slika 5: Lovački dom u Perdasima; snimila Marijeta Rajković, travanj 2008. godine.

Sezona obično traje oko tri mjeseca, s tim da su lovni dani srijeda, subota i nedjelja. Ostalim danima zabranjeno je ići u lov. Članovi Lovačkoga društva mogu bilo kada ići u lov, kad je lovni dan ne moraju se nikome najaviti. Moraju imati sa sobom lovne listove za vrstu oružja koju nose, oružane listove, potvrdu da su platili članarinu za tekuću godinu. Zabranjen je također samostalan lov, moraju biti najmanje tri lovca. Tijekom sezone lova članovi najčešće love zečeve i divlje svinje. No da bi lovci ustrijelili neku životinju moraju imati dozvolu za njen odstrel. Odstrel se dobiva nakon što skupe određen broj bodova. Ja sam lani ima 11000 bodova i bil sam najjači u Društvu, to su bili radni bodovi. I onda sam za dar dobil odstrel jednog jelena, kazao je Milan Pavelić Sikirica iz Pavića, objasnivši kako je skupio svoje radne bodove: Pomoću rada i vremena (...) idem skoro svaki dan, $i$ danas sam bil sa svojim autom, pa se radilo sa mojom mišalicom, sa autom vozim vodu, imam motor na struju (... radimo lokve za životinje. Moji su sugovornici objasnili da je protuvrijednosti jednog boda pet kuna. Primjerice, za odstrijeliti muflona potrebno je sakupiti 3000 bodova, a 8000 za jelena. Nakon što se odstrijeli jelen njegova jetra se nosi kod veterinara u Senj, da se vidi jel'zdrav. Mozak se nosi u Rijeku, to sve sam moraš platit, onda ga odereš. Ako je zdrav može se jest meso. ${ }^{40}$ Nakon odstrela

40 Milan Pavelić Sikirica, Mrzli Dol. 
rogovi jelena lopatara i muflona, te veprove kljove šalju se na ocjenu i dobivaju medalje. ${ }^{41}$ Osim u Senj šalje se na ocjenjivanje u druge hrvatske gradove, pa i inozemstvo (primjerice u Njemačku i Mađarsku). Neovisno o tome koliko se bodova sakupi, zabranjen je lov na divljač koje ima u lovištu u malom broju. $\mathrm{Na}$ ovom je području dugo bila zabrana lova na medvjeda. Zaštićene vrste su: ris, vuk, srna, orao i jastreb. Osim lova, gotovo su svi kazivači navodili da najviše vole kada se poslije lova ide $k$ Žumbercu u gostionu Kod Strica Luke Jebalice ... svira harmoniku: Moj Ivane! I to ti je to. ${ }^{42}$ Otkada je sagrađen Lovački dom na Perdasima u Senjskoj Dragi, najčešće se ondje fešta nakon lova. Mnogi lovci su kroz smijeh kazivali da tako pobjegnu i od žena koje ne mogu kontrolirati koliko alkohola popiju.

Kao što je već spomenuto, lovište ima lovočuvara. Aktualni lovočuvar je Milan Tomljanović Livak iz Bunice, čiji je posao nadgledati lovište, kontrolirati jesu li lovci izvršili zadatke, kad su lovni dani, imaju li skupine najmanje tri lovca, sprečavati krivolov, pregledavati hranilice i pojilišta. Ako uhvati osobu koja je ubila srnu, postupak je, kaže, sljedeći: Oduzmem srnu, oduzmem oružje kojim je to učinjeno ako se opire zovem policiju (...) Oni izidu na očevid (...) to je krivično djelo. Njima se oduzima oružje (...) Što se tiče samog Drusttva takvi članovi koji bi ubili srnu, njih bi predsjednik odmah isključio van i nikad više ne bi bili članovi ovog Društva (...) mogu pregledat vozilo (...) jedino ne smijemo otraga bunker (prtljažnik op.a.). Nakon zatvaranja lovne sezone, također nedjeljom, za članove Društva organizira se skup i skupni lov, nakon čega predstoje samo radovi u lovištu. Lov se zatvara koncem ožujka ili početkom travnja, međutim ako se odstreli kvota koja je dozvoljena lov se može zatvorit i u siječnju. Ako je Društvo odredilo da se može ubiti pet vepra $i$ ako ih se ubije pet do 15. 12. tog datuma je gotov lov na veprove, kazao je tajnik Lovačkoga društva Milan Vukelić Deviza.

\subsection{INOZEMNI LOVCI}

$\mathrm{O}$ d devedesetih godina 20. stoljeća lov je postao dio turističke ponude senjskoga zaleđa. Uglavnom dolaze inozemni lovci iz Austrije, Švicarske i Njemačke u lov na muflone te Talijani u lov na pernatu divljač: prepelice, šljuke i jarebicu kamenjarku. Dolazak talijanskih lovaca isključivo na lov ptica kazivači objašnjavaju: Na pticama ima jedno crijevo koje oni izvade van, imaju neku iglu kao udica, to je crijevo dugo $30 \mathrm{~cm}$. Prodaju ga za izradu kirurškog konca. To se radi od prepelice i šljuke. ${ }^{43}$ Kazivači Lovačkoga društva Jarebica napominjali su da je Društvo prisiljeno baviti se takvim načinom organizacije lova i tumačili da se time smanjuju lovni dani za vlastite članove budući da prednost moraju dati inozemnim lovcima. Opis lova talijanskih lovaca zrcali se u kazivanju aktualnoga lovočuvara: Mi imamo revire u lovištu, to je površina u jednom lovistu, recimo 2-3 hektara. Imamo jednog Talijana koji kod nas zakupi taj dio revira da bi njegovi lovci mogli tu dolazit. On plati taj zakup lovišta. Talijani tu love (...) Naši pratioci su dužni da njih prate, moraju imat lovno odobrenje za te dane na ime i prezime lovca. Jedan talijanski lovac ne može imati više od tri psa na lovištu, i jedan pratioc ne može imat više od tri lovca. Lokalni stanovnici, lovci, prate inozemne lovce i za to dobivaju naknadu. Osim što stranci ne smiju s oružjem sami šetati na prostorima Hrvatske, potrebna im je stručna pratnja koja lovca vodi na određenu divljač, primjerice na šljuku i na pernatu divljač, budući pratitelj treba poznavati stanište životinje. Kada lov završi, predstavnik pratitelja pribavlja lovcima potrebnu dokumentaciju budući da sve životinje prije izlaska iz zemlje mora pregledati veterinar.

Lovne agencije za ovo područje postoje u Senju i u Zagrebu. U Senju postoji agencija za lovni turizam, a velik dio dolazi i preko jedne zagrebačke agencije.

Povećan broj inozemnih turista odražava se na gospodarstvo Senja, međutim, čini se, veoma neznatno: Tereni nisu veliki, nije velika kvota odstrela, medutim odredeni dio njih dolazi s obiteljima i prijateljima ponovno ljeti na godišnji odmor. Tako nastaje lančana reakcija koja doprinosi turističkoj dobiti. ${ }^{44}$

41 Iz Senja su tri člana položila ispit za ocjenjivače trofeja. Osim njih dolaze ocjenjivači iz Županijskog saveza te iz drugih saveza. Ispit za ocjenjivače može se polagati u Zagrebu i Karlovcu.

42 Milan Tomljanović Livak, Bunica.

43 Isti kazivač.

44 Prema kazivanju Milana Vukelića Devize, Senj. 


\section{UMJESTO ZAKLJUČKA}

$\mathrm{P}$ rikupljajući građu za ovu temu kod svakog sam kazivača osjetila ponos što je lovac. Također, dobila sam dojam da je biti lovcem i članom Lovačkoga društva bitan marker identiteta Krivopućana, odnosno Senjana. Da bi se sakupilo bodove, pojedinci imaju velike obveze, a zadovoljstvo su trofeji koji krase njihove kuće. No većina lovaca ipak ne lovi. Mnogi su isticali da godinama nisu ništa odstrijelili i da su članovi Društva više zbog druženja te ljubavi prema prirodi i životinjama. Stav lokalnoga stanovništva prema inozemnim lovcima je dvojak; kod onih koji imaju koristi od njih iznajmljujući smještaj, nudeći im prehranu ili prateći ih u lovu je pozitivan, dok su oni ostali, vlasnici poljoprivrednih zemljišta, protiv ovakvog lova budući da im ptice (koje se dopremaju u lovište) ponekad unište ionako male usjeve, a lovci njive napune mecima. Dakako da je sadašnja površina zemlje koja se obrađuje mala. Stalni su stanovnici uglavnom starija populacija koja se ne može baviti ovom djelatnošću, a mlađi su zaposleni u urbanim središtima i na ove prostore dolaze vikendima i ljeti te se poneki bave samo povrtlarstvom za svoje potrebe. No, Krivopućani su često isticali da im srne i jeleni dolaze i uništavaju usjeve, a divlje svinje kopaju rupe. Stoga stanovnici koji se ipak nastoje baviti zemljoradnjom svoje njive ograđuju ogradama i postavljaju plašila kojima nastoje spriječiti dolazak životinja.

$\mathrm{Na}$ temelju etnološkoga istraživanja, prijedlog bi bio da se u turističku ponudu uvrsti prezentacija tradicijskoga načina lova te prepričavanje priča i anegdota s ciljem upoznavanja raznih životinja i njihova načina života. Kada već dolaze lovci, da povedu i članove obitelji za što je dakako potrebno proširiti turističku ponudu. Boraveći često na terenu imali smo prilike susresti životinje koje se ne boje ljudi. Spomenimo vjeverice koje stoje na cesti i začuđeno promatraju automobil, ali ne odlaze s ceste, pa čak i medvjeda. Stoga pozivam ljubitelje prirode da uz opremu poput dalekozora i fotoaparata dođu uživati na ove prekrasne obronke $s$ još ljepšim pogledom na otoke Hrvatskoga primorja.

\section{LITERATURA}

JURČENKO, Vladimir, Vlatko SKORUP, Krešimir STANIŠIĆ, Branimir TOMLJANOVIĆ, Josip TOMLJANOVIĆ, Dragan VLAHOVIĆ (2005): Jarebica. Izdavač: Lovačka udruga Jarebica Senj, Senj. 